\title{
EFFECT OF TONSILLECTOMY ON NUTRITION IN TWELVE HUNDRED CHILDREN*
}

\author{
ALBERT D. KAISER, M.D. \\ ROCHESTER, N. Y.
}

Tonsillectomy has become a common operation. The indications for this procedure differ. Until recently tonsils were removed only if they were obstructive or presented definite evidence of infection. Marked improvement followed the removal of such tonsils in most instances. In recent years the operation has been recommended as a prophylactic procedure, and so-called potentially diseased tonsils are removed. Much is expected from a tonsillectomy and I believe rightly so if the tonsils are at fault. One is so often impressed with the marked improvement in nutrition after such an operation that the influence of the operation on nutrition cannot be overlooked.

In a clinic in which ten thousand children were subjected to the operation, a study was made of twelve hundred to determine the effect of the operation on nutrition. These children received more or less uniform care having all been operated on in one clinic by the same surgeons and selected for operation by two physicians who followed a uniform standard for the designation of cases for operation. A careful history was taken of each child, and the definite complaints of the child were charted. All the cases were so-called extreme cases with obviously diseased tonsils and adenoids, or presenting complaints definitely referable to a possible focus in the tonsils. Practically all these children were operated on in the summer of 1920 and reexamined from nine to twelve months later. The estimation of the child's nutrition is based on the height-weight relationship. When the children appeared for operation they were measured in stocking feet and weighed without outside clothing. The same children were similiarly measured and weighed at this subsequent examination. Weights and measurements were compared with the table of average weight and height measurements published by Dr. Emerson for the Nutrition Clinics for delicate children.

The children operated on represented the so-called urgent cases. The reasons for operation varied. Many children had large obstructive tonsils and adenoids, others obviously infected tonsils while a few showed no evidence of diseased tonsils but had recurrent infections in the head which could be attributed to the tonsils. There seemed to be a definite indication for operation in each case.

* Received for publication, Nov. 11, 1921.

* From the Nose and Throat Department of the Rochester Dental Dispensary. 
The 1,200 children studied ranged in age from 3 to 15 years. These children presented themselves for operation because of throat symptoms and not because of malnutrition and thus do not represent necessarily a group of malnourished children. No effort was made to place these children in a nutrition class though the school nurse or social service worker had instructed them in habits of life which might have some bearing on their nutritional improvement.

The children were grouped into three classes: (1) Those who were 10 per cent. or more overweight; (2) those who had normal weight or were less than 7 per cent. underweight (so-called borderline cases); (3) those who were 7 per cent. or more underweight. At the time of reexamination the same children were reclassified to determine their nutritional status after the operation.

TABLE 1.-Nutritional Status of Children at Time of Operation

\begin{tabular}{|c|c|c|c|c|c|c|}
\hline \multirow[b]{2}{*}{ 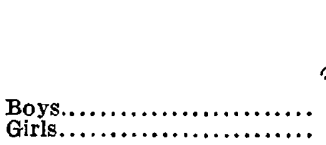 } & \multicolumn{2}{|c|}{$\begin{array}{l}10 \text { Per Cent. or More } \\
\text { Overweight }\end{array}$} & \multicolumn{2}{|c|}{$\begin{array}{l}\text { Normal Weight or } \\
\text { Borderline Cases }\end{array}$} & \multicolumn{2}{|c|}{$\begin{array}{c}7 \text { Per Cent. or More } \\
\text { Onderweight }\end{array}$} \\
\hline & $\begin{array}{c}\text { Number } \\
37 \\
40\end{array}$ & $\begin{array}{c}\text { Per Cent. } \\
3.1 \\
3.9\end{array}$ & $\begin{array}{c}\text { Number } \\
323 \\
381\end{array}$ & $\begin{array}{c}\text { Per Cent. } \\
28 \\
31\end{array}$ & $\begin{array}{c}\text { Number } \\
185 \\
224\end{array}$ & $\begin{array}{c}\text { Per Cent. } \\
15 \\
19\end{array}$ \\
\hline Total.................... & 87 & 7 & 704 & 59 & 409 & 34 \\
\hline
\end{tabular}

In this group of 1,200 children the percentage of malnutrition (34) was about the same as is being found in the schools throughout the city. Though an equal number of girls and boys were examined, it was noted that malnutrition existed in 4 per cent more girls than boys. The age distribution is not significant. More children were underweight between the ages of 5 and 9 than in later childhood.

TABLE 2.-Nutrition Status of Children Nine Months After Operation

\begin{tabular}{|c|c|c|c|c|c|c|}
\hline \multirow[b]{2}{*}{ 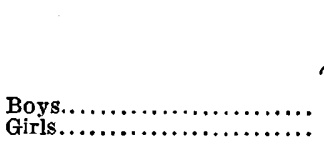 } & \multicolumn{2}{|c|}{$\begin{array}{l}10 \text { Per Cent. or More } \\
\text { Overweight }\end{array}$} & \multicolumn{2}{|c|}{$\begin{array}{l}\text { Normal Weight or } \\
\text { Borderline Gases }\end{array}$} & \multicolumn{2}{|c|}{$\begin{array}{l}7 \text { Per Cent. or More } \\
\text { Underweight }\end{array}$} \\
\hline & $\begin{array}{c}\text { Number } \\
57 \\
67\end{array}$ & $\begin{array}{c}\text { Per Cent. } \\
4.7 \\
5.5\end{array}$ & $\begin{array}{c}\text { Number } \\
425 \\
461\end{array}$ & $\begin{array}{c}\text { Per Cent. } \\
35.5 \\
38.4\end{array}$ & $\begin{array}{c}\text { Number } \\
70 \\
120\end{array}$ & $\begin{array}{c}\text { Per Oent. } \\
5.9 \\
10\end{array}$ \\
\hline Total.................... & 124 & $\overline{10.2}$ & 886 & 73.9 & 190 & 15.9 \\
\hline
\end{tabular}

A reexamination of these children from nine to twelve months after the operation showed a marked improvement in the nutrition. Generally, it can be stated that when the nutrition improved, the symptoms for which the child was operated on were relieved. In order to determine the net gain in weight, the growth of the child had to be taken into consideration. The weight was computed for the child's height, measured as at the original examination, and the entire group reclassified. It was found that in the group of 1,200 children the per- 
centage of malnutrition, or those who were 7 per cent. or more underweight, was 15.9 . In the normal classification were 73.9 per cent. of the group, while 10.2 per cent. were 10 per cent. overweight.

An analysis of the 15.9 per cent. representing 190 children who failed to attain their normal weight shows that other factors besides diseased tonsils are at fault. Englarged cervical glands following tonsillectomy were found in fifteen cases. Pertussis, bronchitis or some other infection, followed the operation in others. Poor home control and improper diet could be traced to others. More careful examinations of this group will need to be made to determine their failure to gain properly.

It is significant, however, that about 50 per cent. of the 409 underweight children should have attained their normal weight for their height in a period of nine months. Without any other efforts to improve their nutrition it seems fair to assume that diseased tonsils and adenoids were at least partly responsible for this condition. It must be stated that not all children improved their status or even held their own, for 7 per cent. of the total number were relatively in poorer nutrition at the time of reexamination that at the time of operation. But of the entire group 219 children showed a very marked nutritional improvement.

Table 3.-Nutritional Improvement Made After Operation

\begin{tabular}{|c|c|c|c|c|}
\hline $\begin{array}{l}\text { At time of operation........................ } \\
\text { Nine months after operation............ }\end{array}$ & $\begin{array}{c}\text { Number } \\
\text { Examined } \\
1,200 \\
1,200\end{array}$ & $\begin{array}{c}\text { Number } \\
\text { Overwelght } \\
87 \\
124\end{array}$ & $\begin{array}{c}\text { Number Nor- } \\
\text { mal Weight } \\
704 \\
\mathbf{8 8 6}\end{array}$ & $\begin{array}{c}\text { Number } \\
\text { Underweight } \\
409 \\
190\end{array}$ \\
\hline
\end{tabular}

\section{CONCLUSIONS}

1. Among 1,200 children operated on for diseased tonsils and adenoids there was 34 per cent. malnutrition ( 7 per cent. or more underweight).

2. Reexamination from nine to twelve months later showed a reduction of malnutrition to 15.9 per cent.

3. Diseased tonsils and adenoids do not necessarily impair nutrition, as evidenced by 66 per cent. of children showing normal weight according to height.

4. Diseased tonsils and adenoids are undoubtedly a factor in malnutrition, as evidenced by the marked improvement in 219 children of the group. 